\title{
三塩化窒素の生成および定量に対するイソシアヌル酸の影響
}

\author{
澤村良二, 立川真理子 \\ 日本大学理工学部薬学科1)
}

\section{Studies on the Formation and Determination of Nitrogen Trichloride under Coexistence of Isocyanuric Acid}

R yoji Sawamura and Mariko TachiKawa

Department of Pharmacy, College of Science and Technology, Nihon University ${ }^{1)}$

(Received January 24, 1980)

Nitrogen trichloride $\left(\mathrm{NCl}_{3}\right)$ is considered as a material with unpleasant odor and causing eye irritation in swimming pool. The formation of $\mathrm{NCl}_{3}$ depends on $\mathrm{pH}$ and molecular ratio of chlorine to ammonia.

When $\mathrm{NCl}_{3}$ was measured by Palin's neutral ortho-tolidine method with oxalic acid, false $\mathrm{NCl}_{3}$ not extracted with $\mathrm{CCl}_{4}$ was observed in the determination of chlorine solution containing a certain organic nitrogen compound such as isocyanuric acid (ICA), hypoxanthine, and dimethyl urea. The false $\mathrm{NCl}_{3}$ disappeared by lengthening the contact time with oxalic acid.

In order to measure $\mathrm{NCl}_{3}$ without influence of coexistence of these compounds, $\mathrm{NCl}_{3}$ was extracted with $\mathrm{CCl}_{4}$, and the chlorine of $\mathrm{NCl}_{3}$ in $\mathrm{CCl}_{4}$ layer was mesured by iodometric method.

By use of this $\mathrm{CCl}_{4}$-extraction method, the effect of ICA on the formation of $\mathrm{NCl}_{3}$ from ammonia and chlorine was studied. The quantity of $\mathrm{NCl}_{3}$ formed decreased by the addition of ICA. Isocyanuric acid had the same effect even when ammonia in solution was in the chemical form of monochloramine $\left(\mathrm{NH}_{2} \mathrm{Cl}\right)$, and dichloramine $\left(\mathrm{NHCl}_{2}\right)$.

When the dose of chlorine was less than that of breakpoint, ammonia in solution was decomposed without producing $\mathrm{NCl}_{3}$. Thus the separate addition of chlorine gave a practical effect on the decrease of $\mathrm{NCl}_{3}$ in the procedure of breakpoint chlorination.

Keywords-nitrogen trichloride; mono- and dichloramine; chlorination; breakpoint phenomenon; residual ammonia nitrogen ; separate chlorination; neutral ortho-tolidine method; isocyanuric acid; hypoxanthine; dimethyl urea

\section{ま え がき}

水道や水泳プールのクロリネーションによって生成す る三塩化窒素 $\left(\mathrm{NCl}_{3}\right)$ は揮発性の物質で, 水道水の不愉 快な臭いの原因の一つであり，2また，水泳プールで目 に刺激を与える物質であるとされている。

White は $\mathrm{NCl}_{3}$ の生成に括䦻る $\mathrm{pH}$ と塩素：アンモ二
ア性窒素との関係を記載し， $\mathrm{NCl}_{3}$ の生成は $\mathrm{pH}$ が低い ほど起こりやすいとし，4a）塩素とアンモニア性窒素の比 をモル比で表わすと， pH 5 以下では1：1で， pH 7 付 近では 1:2(不連続点付近)，pH9では 1:5を越える あたりから $\mathrm{NCl}_{3}$ が生成するとしている。 また Palin は 遊離塩素が存在しないときは， $\mathrm{NCl}_{3}$ もほとんど生成し

1) Location : 1-8 Kandasurugadai Chiyoda-ku, Tokyo (東京都千代田区神田駿河台1-8).

2) D. B. Williams, $J . A W W A$., 58, 249 (1966).

3) A.T. Palin, Proc. Nat. Assoc. Baths Superintendents., 20, 78 (1950).

4) a) G.C. White, "Handbook of Chlorination," Van Nostrand Reinhold Company, New York, 1972, p. $195 ;$ b) Idem, ibid., p. 195 , p. 298 , p. 379. 
ていないとしている.5

$\mathrm{NCl}_{3}$ を他の有效塩素と区別して測定する方法に， DPD 法, ${ }^{5)}$ 中性オルトトリジン法6)などがある。中性才 ルトトリジン法では，遊離塩素測定操作を行ら時，その 分画の読み取り值には, 遊離塩素の全量と $\mathrm{NCl}_{3}$ の 2 分 の 1 量が含をれている。このことを利用して $\mathrm{NCl}_{3}$ を定 量する方法が二つ記載されている。一つは試料溶液にシ ニウ酸を加穴て遊離塩素のみを分解する方法である. 遊 離塩素は15分以内に完全に分解されるが, $\mathrm{NCl}_{3}$ は残って いる，旮こで15分後に遊離塩素湘定操作を行って，その 読み取り值を 2 倍して $\mathrm{NCl}_{3}$ とすることができる，他の 一つ試料溶液を四塩化炭菜 $\left(\mathrm{CCl}_{4}\right)$ 抽出して $\mathrm{NCl}_{3}$ の みを除去する方法である。李ず試料溶液を $\mathrm{CCl}_{4}$ で抽出 して $\mathrm{NCl}_{3}$ を除いた後, 遊離塩素測定操作を行い, 実際 に存在する遊離塩素の值を得る。次に，同一試料につい て，抽出を行わずにただちに遊離塩素测定操作を行ら。 この読み取り値から, 実際に存在する遊離塩素の值を差 し引いた值が， $\mathrm{NCl}_{3}$ の 2 分の 1 に相当するので， 2 倍 して $\mathrm{NCl}_{3}$ とすることができる。

著者らが，今回遊離塩素とイソシアヌル酸 (以下 ICA と記す）の混合水溶液について，この三つの方法で測定 を行ったところ，雨法の結果に大さな違いがあることが わかった、すなわち, 後者の方法では, $\mathrm{CCl}_{4}$ 抽出の前 後で遊離閔素としての滴定值に変化がないにもかかわら ず，前者の方法では，シュウ酸で消えない塩素が存在 し，あたかも $\mathrm{NCl}_{3}$ が存在するよらな結果が得られた。 このよらな現象は ICA 以外に, ジメチル尿素, ヒポキ サンチンなどについても認められた。

水溶液中の $\mathrm{NCl}_{3}$ は $\mathrm{CCl}_{4}$ によって效率よく抽出され るので, $\mathrm{CCl}_{4}$ 層についてヨウ素法により定量することが できる.6,7この方法によってアンモニアと塩素の不連続 点反応における $\mathrm{NCl}_{3}$ 生成量に対する ICA の影響を検討 したところ，ICA の存在によって生成する $\mathrm{NCl}_{3}$ 量は減 少した，そこで反応条件と $\mathrm{NCl}_{3}$ 生成量の関係について 検討を加えたので報告する。

\section{実 験 方 法}

実験材料および試薬有機窒素化合物——ピキサ ソチン,ジチル尿素, ピログルタミン酸(いずれも東 京化成製特級).インシアヌル酸（四国化成製）は熱湯 中より再結晶を2 回行った。
塩素刜——次西塩素酸ナトリウム(和光純蒋製). ク口 ラミン B (東京化成製). ジクロルイソシアヌル酸ナト リウム(四国化成製)。トリクロルイソシアスル酸（日産 化学製).グルタミン酸脱水素酵素液 ( $\mathrm{PL}$ 社製). 程化 アンモニウム以下，その他の試薬はできるだけ特級を用 いた。

測定法中性オルトトリジン法による, 遊離塩素, モノクロラミン $\left(\mathrm{NH}_{2} \mathrm{Cl}\right)$, ジクロラミン $\left(\mathrm{NHCl}_{2}\right)$ の分 離定量 ${ }^{6}$ ——遊離塩素量は, 試料溶液 $100 \mathrm{ml}$. $\mathrm{pH}$ 約 6のリン酸一へキサメタリン酸緩衝液 $5 \mathrm{ml}$ 上中性オルト トリジン溶液 $5 \mathrm{ml}$ の混合液中に加えて青色呈色させ， ただちに硫酸第一鉄アンモニウム溶液 $(1.0 \mathrm{ml}$ が 0.1 $\mathrm{mg} \mathrm{Cl}$ に相当する）で無色となるまで滴定して得る。 $\mathrm{NCl}_{3}$ を含まない時は，この值が遊離塩素である。

$\mathrm{NH}_{2} \mathrm{Cl}$ 量は，遊離塩素滴定後さらに $0.2 \%$ ウ ウ化力 リウム溶液 $1 \mathrm{ml}$ を加えた時に呈色する部分を滴定した 値である。

$\mathrm{NHCl}_{2}$ 量は, $\mathrm{NH}_{2} \mathrm{Cl}$ 滴定後 $6 \%$ 硫酸溶液 $1 \mathrm{ml}$ 加之 て呈色させ，1分後に5\%炭酸水素ナトリウム溶液を加 えた後に㵜定して得た值である。

$\mathrm{NCl}_{3}$ の定量— 1. シュウ酸を用いる中性オルト卜 リシンン法6)：リン酸一へキサメタリン酸緩衝液 $(\mathrm{pH}$ 約 6) $5 \mathrm{ml}, 2 \%$ シュウ酸 $5 \mathrm{ml}$ を混合し，これ火陚料溶液 $100 \mathrm{ml}$ 加兄る。1 15 分間放置後，5\%炭酸水素ナトリ ウム溶液と, 中性オルトトリジン溶液と $5 \mathrm{ml}$ をずつ加 えて, 青色が消えるまで硫酸第一鉄アンモ二ウム溶液で 滴定する。この滴定値から得られた有效塩装量の2 倍し たものを $\mathrm{NCl}_{3}$ の塩素量とする。

2. $\mathrm{CCl}_{4}$ 抽出によるヨウ素滴定法： $\mathrm{NCl}_{3}$ を含む試料 溶液 $100 \mathrm{ml}$ に対して $10 \mathrm{ml}$ の $\mathrm{CCl}_{4}$ を加えて振と5し， $\mathrm{CCl}_{4}$ 層を分取する。この $\mathrm{CCl}_{4}$ 層を $2 \%$ シュウ酸 $5 \mathrm{ml}$ とリン酸一へキサメタリン酸緩衝液 $5 \mathrm{ml}$ との混合液で洗 った後，共栓三角フラスコ中に移し，50\%酢酸溶液 10 $\mathrm{ml}$ とヨウ化カリウム $0.5 \mathrm{~g}$ を加えてよく振り，水溶液中 に遊離したヨウ素を $0.01 \mathrm{~N}$ チオ硫酸ナトリウム溶液で 滴定し, 得られた塩素量を $\mathrm{NCl}_{3}$ の塩素量とする。

酵素によるアンモニア性窒素の定量 ${ }^{8}$ 一一千オ硫酸ナ トリウム溶液を加えて残留塩素を消した試料溶液 $1 \mathrm{ml}$ に, ジとドロニコチンアミドアデニンジヌクレオチド

$(\mathrm{NADH})+\alpha$ タトグルタル酸溶液 $1 \mathrm{ml}$, グルタミン

5) "Standard Methods for the Examination of Water and Wastewater," 14 th ed. American Public Health Association, Washington DC, 1975, pp. 331-333.

6) A. T. Palin, Water \& Sewage Works., 101, 74 (1954).

7) C. T. Dowell, W.C. Bray, J. Am. Chem. Soc., 39, 896 (1971).

8) 澤村良二, 吉田京子, 平木映子, 衛生化学, 24, 96 (1978). 

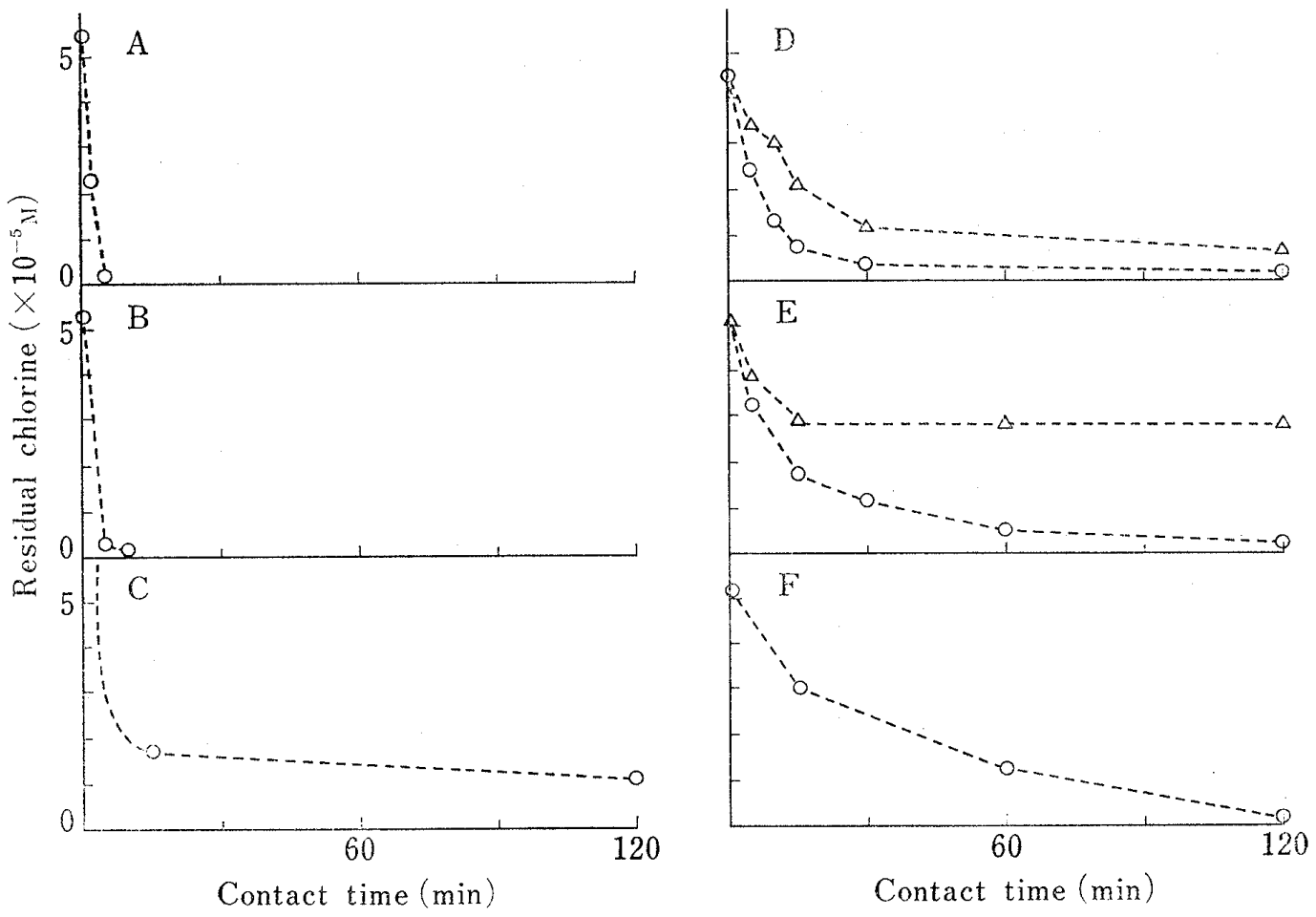

Fig. 1. Residual Chlorine after Contact with Oxalic Acid

A : chlorine (NaOCl) $5.45 \times 10^{-5} \mathrm{M}$; $\mathrm{B}$ : pyroglutamic acid $5.24 \times 10^{-5} \mathrm{M}$, chlorine $5.24 \times 10^{-5} \mathrm{M}$; $\mathrm{C}: \mathrm{NH}_{4} \mathrm{Cl} 4.85 \times 10^{-5} \mathrm{M}$, chlorine $33.38 \times 10^{-5} \mathrm{M} ; \mathrm{D}: \mathrm{ICA} .2 .32 \times 10^{-4} \mathrm{M}(30 \mathrm{mg} / \mathrm{l}) \cdots \mathrm{O} \cdots, 15.47 \times 10^{-4} \mathrm{M}$ $(200 \mathrm{mg} / 1) \cdots \triangle \cdots$, chlorine $4.48 \times 10^{-5_{\mathrm{M}}} ; \mathrm{E}$ : hypoxanthine $5.10 \times 10^{-5} \mathrm{M} \cdots \circ \cdots, 20.00 \times 10^{-5} \mathrm{M}$ $\cdots \triangle \cdots$, chlorine $5.10 \times 10^{-5} \mathrm{MI} ; \mathrm{F}:$ dimethyl urea $5.07 \times 10^{-5} \mathrm{M}$, chlorine $5.10 \times 10^{-5} \mathrm{M}$.

Each organic nitrogen compound and chlorine were previously reacted for $10 \mathrm{~min}$, in the Sample Solution to the mixture of $5 \mathrm{ml}$ of $2 \%$ oxalic acid and $5 \mathrm{ml}$ of hexametaphosphate buffer, $100 \mathrm{ml}$ of sample solution was added and left each contact time. The residual chlorine was titrated with ferrous ammonium sulfate solution, after the addition of $5 \mathrm{ml}$ of $5 \%$ sodium bicarbonate and of neutral $o$-tolidine solution.

酸脱水素酵素溶液 $0.02 \mathrm{ml}$ を加之て, 15 分後に $340 \mathrm{~nm}$ の吸光度を測定する. 吸光度の減少量から検量線法によ ってアンモニア性窒素の量を求めた.

\section{結果と考察}

\section{I. 遊離塩素とシュウ酸との反応に対する共存物質の} 影響

有効塩素約 $5 \times 10^{-5} \mathrm{M}(3.5 \mathrm{mg} / \mathrm{l})$ を含む次亜塩素酸 ナトリウム水溶液に種々の有機窒素化合物を当モルない し 2-4 倍モルの割合で加えて10分間反応させた後, 中 性オルトトリジン法で遊離塩素, $\mathrm{NH}_{2} \mathrm{Cl}, \mathrm{NHCl}_{2}$ を測 定した. 有機窒素化合物としてピログルタミン酸, ICA， ヒポキサンチン，ジメチル尿素を加えた時，塩素消費は なく、ずでて遊離型として測定された。

上記の 有機窒素化合物-塩素溶液に $2 \%$ シュウ酸を加 光，中性オルトトリジン法で $\mathrm{NCl}_{3}$ 測定を行った。 その 時のシュウ酸との反応時間と残留塩素との関係を Fig. 1 に示す. 塩化アンモニウムについては, 約 7 倍モルの塩
素を加えて $\mathrm{NCl}_{3}$ を生成させた後シュウ酸と反応させ た。

次車塩荸酸ナトリウムだけを含む水溶液中の塩素は， $2 \%$ ュウ酸を加えると 5 分以内に消失する．有機窒素 化合物のらちピログルタミン酸が共存しても消失速度に は変化がない，しかし，ICA，七ポキサンチン，ジメチ ル尿素が共存する時には消失速度が遅くなり，共存物質 の濃度が高くなるほど遅延が著しい。

以上のことから，水溶液中の遊離塩素とシュウ酸との 反応は，共存する物質によっては反応速度が遅くなり， 遊離塩素が残留するため $\mathrm{NCl}_{3}$ の測定值に正の誤差を与 えることがわかった。

\section{II. $\mathrm{NCl}_{3}$ の $\mathrm{CCl}_{4}$ 抽出および定量}

次两塩素酸と塩化アンモニウムとを濃度をかえて反応 させ，生成した $\mathrm{NCl}_{3}$ の塩素量を，シュウ酸を用いる中 性オルトトリジン法と， $\mathrm{CCl}_{4}$ 抽出によるヨウ素㵜定法 を用いて測定し比較した，その結果をTable Iに示す。 
TABLE I. $\mathrm{NCl}_{3}$ formed from Chlorine and Ammonia

Comparable Results by Neutral orthoTolidine Method ${ }^{\alpha}$ a and by $\mathrm{CCl}_{4}$ Extraction Method $^{b)}$

\begin{tabular}{|c|c|c|}
\hline Chlorine dose & 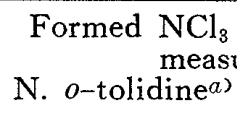 & $\begin{array}{l}\text { as chlorine } \mathrm{mg} / \mathrm{l} \\
\text { red by } \\
\left.\mathrm{CCl}_{4} \text { extract. }{ }^{b}\right)\end{array}$ \\
\hline 5.35 & 0 & 0 \\
\hline 10.70 & 2.85 & 2.48 \\
\hline 22.93 & 4.86 & 4.41 \\
\hline
\end{tabular}

$\mathrm{NH}_{3}-\mathrm{N} 0.68 \mathrm{mg} / 1$, pH 6.3 (1/150 M phosphate buffer).

a) Nitrogen trichloride was determined according to the procedure described in Fig. 1. The contact time with oxalic acid was $15 \mathrm{~min}$.

b) Nitrogen trichloride in $100 \mathrm{ml}$ of sample solution was extracted with $10 \mathrm{ml}$ of $\mathrm{CCl}_{4}$. The $\mathrm{CCl}_{4}$ layer was transferred to the flask in which $10 \mathrm{ml}$ of $50 \%$ acetic acid and $0.5 \mathrm{~g} \mathrm{KI}$ were previously placed, and shaken well. The released $\mathrm{I}_{2}$ was titrated with $0.01 \mathrm{~N} \mathrm{Na}_{2} \mathrm{~S}_{2} \mathrm{O}_{3}$ solution.

$\mathrm{CCl}_{4}$ 抽出によるものがやや小さい值を示した。試料 溶液加らの $\mathrm{NCl}_{3}$ の抽出は溶液量の 10 分の 1 量の $\mathrm{CCl}_{4}$ で1回行っているが，Palin はこの条件でほ济完全に抽 出されるとしている.6) 著者らもこの抽出条件で支障の ないことを認めた。 Dowell らは $\mathrm{CCl}_{4}$ 抽出した $\mathrm{NCl}_{3}$ の 酸性でのヨウ化カリウムによる還元では，一部が窒素ガ スになり， $\mathrm{NCl}_{3}$ の有効塩素をすべて測定することはで きないとしている.フPalin は $\mathrm{CCl}_{4}$ 中の $\mathrm{NCl}_{3}$ のヨウ萻 滴定法の回収率を91\%と報告している.6) したがって， Table I にお㳡る定量值の差はこのような定量操作上の 誤差の一因であると考える.

$\mathrm{NCl}_{3}$ を $\mathrm{CCl}_{4}$ で抽出する時の共存物質の影響を見るた め, 中性の次覀素塩酸溶液, 中性でアンモニア-次雨塩 素酸反応によって生成した $\mathrm{NH}_{2} \mathrm{Cl}$ と $\mathrm{NHCl}_{2}$ ，クロラミ ン $\mathrm{B}$ 溶液, ジクロルイソシアヌル酸ナトリウム溶液を $\mathrm{CCl}_{4}$ で抽出したが，これらの有効塩素は移行しなかっ た.

トリクロルイソシアスル酸の場合には, 有効塩素はわ ずかに $\mathrm{CCl}_{4}$ 層に移行するが, $\mathrm{CCl}_{4}$ 層を $2 \%$ シュウ酸溶 液で洗うことにより消失する。また，中性の次亜塩素酸 溶液中に ICA やヒポキサンチンが共存する場合も，そ の有効塩素は $\mathrm{CCl}_{4}$ 層には移行しなかった。

以上のことから, $\mathrm{NCl}_{3}$ を $\mathrm{CCl}_{4}$ 抽出する方法は, ICA などの干渉物質が共存する時の $\mathrm{NCl}_{3}$ の定量に適してい る.

III. 三塩化窒素生成に対するイソシアヌル酸の影響 pH 6.3で, ICA 濃度がそれぞれ 0.5, 30, $200 \mathrm{mg} / 1$,

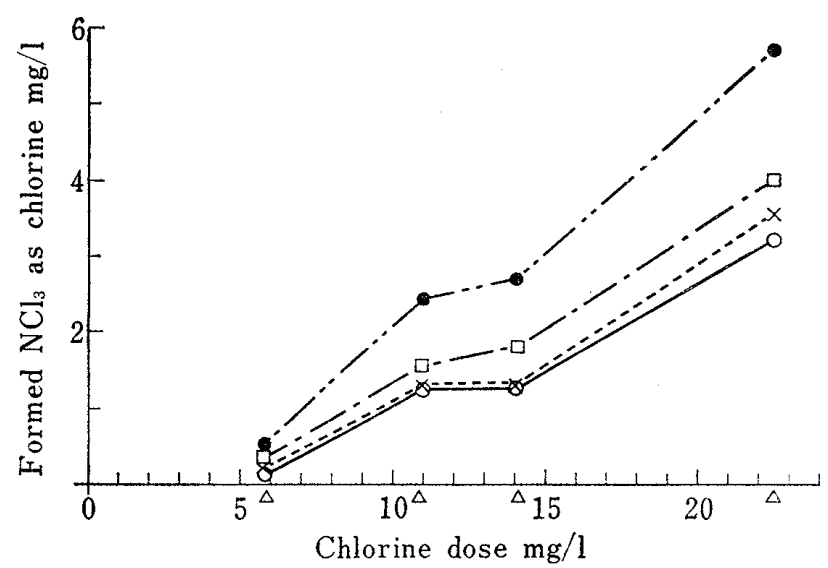

Fig. 2. Effect of Isocyanuric Acid on the Formation of $\mathrm{NCl}_{3}$

pH 6.3 (1/150 $\mathrm{M}$ phosphate buffer), $\mathrm{NH}_{3}-\mathrm{N} 0.68 \mathrm{mg} / 1$ $\left(4.85 \times 10^{-5} \mathrm{M}\right)$, reaction time $1 \mathrm{hr}$.

Chlorine of $\mathrm{NCl}_{3}$ was measured by $\mathrm{CCl}_{4}$ extraction method described in Table I.

ICA concentration ; - - : : $0 \mathrm{mg} / \mathrm{l},-\square-: 5 \mathrm{mg} / \mathrm{l}$, $\cdots \times \cdots: 30 \mathrm{mg} / 1, \quad \bigcirc-: 200 \mathrm{mg} / 1$

アンモニア性窒素 $0.68 \mathrm{mg} / 1$ を含む水溶液に，次雨塩素 酸を加光，生成した $\mathrm{NCl}_{3}$ を $\mathrm{CCl}_{4}$ で抽出し，ヨウ素法で 滴定した。皇の結果を Fig. 2 に示す。

$\mathrm{NCl}_{3}$ の生成量は，加える次亜塩素酸の量が多くなる につれて增加するが，ICA の共存により減少がみられ る. ICA 濃度が增加するにつれて $\mathrm{NCl}_{3}$ 量は減少する が，その効果は ICA が $30 \mathrm{mg} / \mathrm{l}$ 以上になるとほぼ一定 になる．

そこで $\mathrm{NCl}_{3}$ の測定と並行して反応液についてヨウ素 法による総塩素の測定および酵素法によるアンモニアの 測定を行った。その結果をモル濃度であらわし，Table IIに示す。

不連続点付近の実験（モル比1.9）では， $\mathrm{NCl}_{3}$ の生成 がみとめられず，ICAを含まないものは，総残留塩素， 残留アンモニアも極小值となっている。 しかし，ICA が共存すると塩素消費とアンモニアの分解が抑制され， 不連続点に変化が起こる.

モル比が3を越える実験では， $\mathrm{NCl}_{3}$ が認められ， $\mathrm{NCl}_{3}$ 量と関連してアンモニア量も增減している，特に モル比 3.36 で行った実験の場合は, $\mathrm{NCl}_{3}$ の生成がみと められ，残留アンモニアも存在する。このとき, $\mathrm{NCl}_{3}$ の塩素と残留アンモニアとのモル比は Table II 火示す ようと約 $3: 1$ である.このモル比 3.36 の条件下では, $\mathrm{NCl}_{3}$ と共存する有効塩素は主として遊離塩素であり, $\mathrm{NCl}_{3}$ 以外のクロラミンは活とんど存在せず，また遊敨 アンモニアも存在する可能性がない.97 $\mathrm{NCl}_{3}$ の $\mathrm{N}: \mathrm{Cl}$ モル比の理論值が 1:3であるから，これは $\mathrm{NCl}_{3}$ が残 
TABLE II. Effect of ICA to the Residuals in the Mixture of Chlorine and Ammonia

\begin{tabular}{|c|c|c|c|c|c|}
\hline $\begin{array}{l}\text { Molecular } \\
\text { ratio } \\
\mathrm{Cl}_{2} / \mathrm{NH}_{3}-\mathrm{N}\end{array}$ & $\begin{array}{l}\text { Chlorine dose } \\
\times 10^{-5} \mathrm{M}\end{array}$ & $\begin{array}{l}\text { ICA dose } \\
\times 10^{-5} \mathrm{M}\end{array}$ & $\begin{array}{l}\text { Total residual } \\
\text { chlorine } \\
\times 10^{-5} \mathrm{M}\end{array}$ & $\begin{array}{l}\text { Residual } \\
\mathrm{NH}_{3}-\mathrm{N} \\
\times 10^{-5} \mathrm{M}\end{array}$ & $\begin{array}{l}\text { Formed } \mathrm{NCl}_{3} \\
\text { as chlorine } \\
\times 10^{-5} \mathrm{M}\end{array}$ \\
\hline 1.96 & 9.17 & $\begin{array}{r}0 \\
4.85 \\
24.25\end{array}$ & $\begin{array}{l}0.26 \\
6.53 \\
6.53\end{array}$ & $\begin{array}{l}0.48 \\
2.60 \\
2.88\end{array}$ & $\begin{array}{l}0 \\
0 \\
0\end{array}$ \\
\hline 3.36 & 15.28 & $\begin{array}{c}0 \\
4.85 \\
24.25\end{array}$ & $\begin{array}{l}6.79 \\
6.79 \\
6.79\end{array}$ & $\begin{array}{l}0.86 \\
0.31 \\
0.31\end{array}$ & $\begin{array}{l}2.35 \\
1.31 \\
1.04\end{array}$ \\
\hline 4.72 & 22.91 & $\begin{array}{c}0 \\
4.85 \\
24.25\end{array}$ & $\begin{array}{l}15.11 \\
14.59 \\
14.12\end{array}$ & $\begin{array}{l}2.19 \\
1.71 \\
1.13\end{array}$ & $\begin{array}{l}4.17 \\
3.91 \\
2.21\end{array}$ \\
\hline
\end{tabular}

Initial $\mathrm{NH}_{3}-\mathrm{N} 4.85 \times 10^{-5} \mathrm{M}, \mathrm{pH} 6.31 / 150 \mathrm{M}$ phosphate buffer, reaction time $1 \mathrm{hr}$.

Total residual chlorine was measured by iodometric method. Chlorine of $\mathrm{NCl}_{3}$ was measured by $\mathrm{CCl}_{4}$ extraction method described in Table I. Ammonia nitrogen was measured by enzymic method using 'glutamate dehydrogenase after the chlorine in sample solution was removed by sodium thiosulfate.

TABLE III. Nitrogen Trichloride formed by Separate Addition of Chlorine to Ammonium Chloride Solution

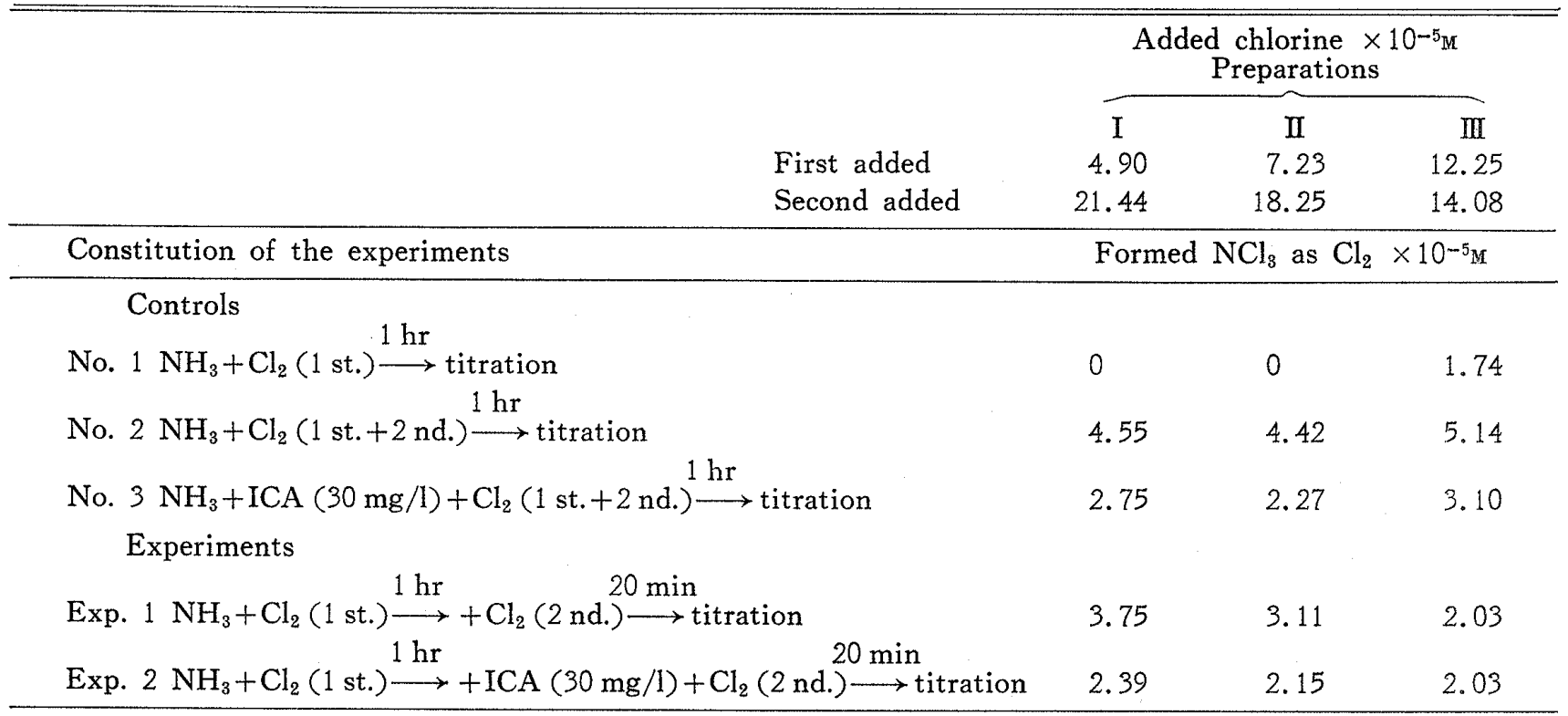

$\mathrm{NH}_{3}-\mathrm{N}: 4.85 \times 10^{-5} \mathrm{M}, \mathrm{pH} 6.3\left(1 / 150_{\mathrm{M}}\right.$ phosphate buffer).

Chlorine of $\mathrm{NCl}_{3}$ was measured by $\mathrm{CCl}_{4}$ extraction method described in Table I

留アンモニアとして，グルタミン酸脱水素酵素を用いた 測定方法によって測定されたものと考光られる。

\section{IV. 残留アンモニア量と $\mathrm{NCl}_{3}$ 生成の関係}

塩素ーアンモニアの反応では残留塩素の不連続点の形 成と関連して残留アンモニア量にも不連続点が認められ る.このことについては，Griffin らの報告9を引用し た Whiteの不連続点図からも明らかである.4b そこで 添加塩素の総量を，アンモニアの約5倍モルとし，この 壏素を Table III の Exp. 1, Exp. 2のように, 2 回に
分けて作用させる実験を試みた。

分割した作用塩素量はIーIIIの3種である. 対照とし て，第 1 回目の塩素量だけを反応させたものと，全量を 1 度に作用させたものについても生成する $\mathrm{NCl}_{3}$ 老測定 した、第 1 回目の塩素添加で $\mathrm{NCl}_{3}$ を生成していないも のも，第 2 回目の 塩素添加によって, $\mathrm{NCl}_{3}$ を生成し た。

塩素の全量を 1 度に加えた Control No. 2 と比べて， 塩素を 2 度に分けて加党た Exp. 1 の $\mathrm{NCl}_{3}$ 生成量は, 減

9) a) A.E. Griffin, N.S. Chamberlin, J. NEWWA., 55, 371 (1941); b) A.E, Griffin, Fifth Anmual Water Conf. Proc. Engrs. Soc. Western Penn., 1944, 27. 
少する.この実験で， I， II，IIIの第 1 回目の塩素添加 量は，それぞれアンモニアに対してモル比約1.0，1.5, 2.5，であるが，この範团では第 1 回目の塩素添加量が 多くなるにしたがい，2回目の笽素添加による $\mathrm{NCl}_{3}$ の 生成量は滅少している。不連続点以前の塩素添加量で は，添加塩素量が增加するに従って，残留アンモニアが 減少するので，このことと Exp. 1 の実験結果が一致し ている. Exp. 2 は 2 回目の塩素添加の際に ICA を加兊 た実験であるが，Exp. 1 よりさらに $\mathrm{NCl}_{3}$ 生成量は減少 する. IIIの場合には，Control No.1 のデーターが示す ように，第1回目の塩素作用で，すでに $\mathrm{NCl}_{3}$ の生成が 認められる.これ江回目の塩素を加えてもExp. 1 の データーのと教り， $\mathrm{NCl}_{3}$ の增量はわずかであり，Exp. 2 との比較から明らかなように，ICA 添加による減少 死認めら礼ない。

\section{V. 三塩化窒素の生成機構と ICA による抑制効果に ついての考察}

$\mathrm{NCl}_{3}$ 生成反応を含むアンモニアー次雨塩素酸の不連続 点反応については種々の報告があるが，不連続点塩素処 理の反応諭に関するSaunierらの報告10)では，次のよう な反応経路を想定している。

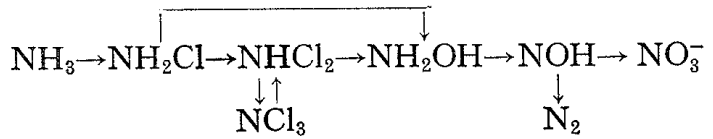

本報に記載した著者らの知見拉よび Griffin らのアン モニアー次雨塩素酸反応の知見 ${ }^{9)}$ を総合すると, 中性溶 液中でのアンモニアからの $\mathrm{NCl}_{3}$ 拈よび $\mathrm{N}_{2}$ 生成と, 反 応モル比（次夾塩素酸/アンモニア）との関係は次のよ らになる。

不連続点を形成するモル比以下では $\mathrm{NCl}_{3}$ 生成反応は 起こらず， $\mathrm{N}_{2}$ 生成を主反応とする塩素消費のみである. $\mathrm{N}_{2}$ 生成に必要な塩素消費量はアンモニアモルに対して 1.5モルであり，実際の不連続点では通常 1.7-1.8モル の塩素消費があるので， $\mathrm{N}_{2}$ 生成以外の塩素消費反応が 多少起こっているものと考光られる. ${ }^{11}$ 不連続点を形成 するモル比以上では，塩素消費と $\mathrm{NCl}_{3}$ 生成が执こるた め, $\mathrm{NCl}_{3}$ 型の残留アンモニアが增加するので $\mathrm{N}_{2}$ 生成 反忘は減少しなければならない。さらに $\mathrm{NCl}_{3}$ 生成は, 添加塩素のモル比が大になる注ぞ增大するので，それに つれて $\mathrm{N}_{2}$ 生成の減少が著しくなるはずである.

この上うに不連続点を形成するモル比以下での塩素化 反応では $\mathrm{NH}_{3} \rightarrow \mathrm{NH}_{2} \mathrm{Cl} \rightarrow \mathrm{NHCl}_{2}$ が主で，同時に塩素消
費を伴亏酸化反応 $2 \mathrm{NH}_{3}+3 \mathrm{Cl}_{2} \rightarrow \mathrm{N}_{2}+6 \mathrm{HCl}$ む史り，不連 続点を形成するモル比以上での 塩素化反応は $\mathrm{NHCl}_{2} \rightarrow$ $\mathrm{NCl}_{3}$ が主となって，塩素消費を伴う， $2 \mathrm{NHCl}_{2} \rightarrow \mathrm{N}_{2}+$ $2 \mathrm{HCl}$ が㧕制されるという想定が成り立つ.

Table II 和上びIII の結果をまとめてみると，次のよ らになる。すなわら， $\mathrm{NH}_{3}$ からだけでなく， $\mathrm{NH}_{2} \mathrm{Cl}$, $\mathrm{NHCl}_{2}$ ，からも $\mathrm{NCl}_{3}$ が生成する。交た， $\mathrm{NH}_{3}$ に不連続 点以下の塩素を作用させると，モル比によっては残留す る $\mathrm{NH}_{3}, \mathrm{NH}_{2} \mathrm{Cl}, \mathrm{NHCl}_{2}$ などの窒素合計量は隇少する ので，これに塩素を追加した場合 $\mathrm{NCl}_{3}$ の生成量も減少 する.ところが, ICA が共存する時には, $\mathrm{NH}_{3}$ に不連続 点以下の塩素を作用させると, 残留する $\mathrm{NH}_{3}$ 量 $\left(\mathrm{NH}_{3}\right.$, $\mathrm{NH}_{2} \mathrm{Cl}, \mathrm{NHCl}_{2}$ 含を) は，むしろ增加している，その 一方, ICA の $\mathrm{NCl}_{3}$ 生成㧕制作用は, $\mathrm{NH}_{3}$ からの $\mathrm{NCl}_{3}$ 生成の場合だけでなく, $\mathrm{NH}_{2} \mathrm{Cl}, \mathrm{NHCl}_{2}$ からの $\mathrm{NCl}_{3}$ 生 成の場合にも認められる，以上のことから，ICAによる $\mathrm{NCl}_{3}$ 生成抑制の直接の原因は, 溶液中の $\mathrm{NH}_{3}$ 拉よび $\mathrm{NH}_{2} \mathrm{Cl}, \mathrm{NHCl}_{2}$ の分解，消失によるものではないこと が明らかになった。

したがって, $\mathrm{NCl}_{3}$ 生成に対する ICA の抑制機構を解 明するためには， $\mathrm{NH}_{3}$ の塩素処理にお打る塩素化反応 および塩素消費反応の関係など， $\mathrm{NCl}_{3}$ 生成に関する基 本的な機構の検討を，より詳細に行うことが必要である と教える。

\section{結論}

1. 中性に括ける $\mathrm{NH}_{3}$ の塩素処理で $\mathrm{NCl}_{3}$ が生成す るには, 反応時に $\mathrm{NH}_{3}, \mathrm{NH}_{2} \mathrm{Cl}, \mathrm{NHCl}_{2}$ のいずれかが 存在し, かつ, こ机らのアンモニア性空素に対して不連 続点を越える有効塩素が添加されていることが条件と なる。不連続点では $\mathrm{NCl}_{3}$ は渒とんど生成せざ，また， $\mathrm{NH}_{3}$ 预よび $\mathrm{NH}_{2} \mathrm{Cl}, \mathrm{NHCl}_{2}$ も汪とんど残留しないの で，塩素の分割添加によって不連続点処理を行党ば，生 成する $\mathrm{NCl}_{3}$ 量を減少させることができる.

2. 塩素安定郕として利用されているICA は, $\mathrm{NH}_{3}$ からの $\mathrm{NCl}_{3}$ 生成量を減少させることを見出した。この $\mathrm{NCl}_{3}$ 生成抑制効果が認められる ICA 濃度は，通常の 塩素安定效果を現わす濃度と一致する。

3. 中性オルトトリジン法に上る $\mathrm{NCl}_{3}$ の分離定量に おいてシュウ酸の遊離塩素分解性が利用されているが， シュウ酸による遊離塩素分解反応の反応速度を低下させ る物質があることを見出した。 そのような物質として， ICA，ヒポキサンチン，ジメチル尿素などがあり，これ

10) B. M. Saunier, R.E. Selleck, J. AWWA., 71, 164 (1979).

11）澤村良二，変異原之毒性，7，39（1979）. 
No. 3

らの共存下では, 中性オルトトリジン法による $\mathrm{NCl}_{3}$ の 測定值に正の誴差が生じ， $\mathrm{NCl}_{3}$ が存在しない場合でも あたかも $\mathrm{NCl}_{3}$ が存在するような結果を与える。しか
し, $\mathrm{Cl}_{4}$ によって直接 $\mathrm{NCl}_{3}$ を抽出して測定する方法 をとれば，ICA などが共存していても，添ぼ定量的に $\mathrm{NCl}_{8}$ を測定することができる。 